\title{
Determination of virulence and antibiotic resistance pattern of biofilm producing Listeria species isolated from retail raw milk
}

\author{
Kamelia M. Osman ${ }^{1 *}$, Ahmed Samir ${ }^{1}$, Usama H. Abo-Shama², Essam H. Mohamed ${ }^{3}$, Ahmed Orabi ${ }^{1}$
} and Tara Zolnikov ${ }^{4}$

\begin{abstract}
Background: One of the foodborne pathogens is Listeria monocytogenes, which causes serious invasive illness in elderly and immunocompromised patients, pregnant women, newborns and infants ranking second after salmonellosis because of its high case fatality rate. Listerial cow mastitis marked by abnormal milk, increased cell counts and reduced production has not been reported. Therefore, apparently healthy cows can be reservoirs of L. monocytogenes. A number of 203 udder milk samples from apparently healthy animals (buffalo, $n=100 ;$ cow, $n=103$ ) were collected and tested for Listeria. Isolated colonies on the PALCAM agar were Listeria species confirmed according to their biochemical and the Christie-Atkins-Munch-Petersen (CAMP) reactions. The Listeria species pathogenicity of was tested by phosphatidylinositol-specific phospholipase C, DL-alanine- $\beta$-naphthylamide $\mathrm{HCl}$, Dalanine-p-nitroanilide tests, chick embryo, mice inoculation tests, Vero cell cytotoxicity and biofilm formation. The virulence-associated genes, hlyA, plcB, actA and iap associated with Listeria were molecularly assayed.
\end{abstract}

Results: The 17 isolated Listeria spp. represented a prevalence rate of $8.4 \%$. Of these 3 (1.4\%), 2 (1 \%), 5 (2.5\%), 4 (2 \%) and $3(1.5 \%)$ were confirmed as L. monocytogenes, L. innocua, L. welshimeri, L. seelegeri, respectively. While the L. monocytogenes isolate displayed all the four virulence-associated genes, L. seelegeri carried the hlyA gene only. The $L$. monocytogenes had a strong in vitro affinity to form a biofilm, in particular serotype 4 which is associated with human infections. L. monocytogenes showed resistance for 9/27 antibiotics.

Conclusions: The biofilm forming capability of the Listeria spps. makes them particularly successful in colonizing surfaces within the host thus being responsible for persistence infections and due to their antimicrobial resistant phenotype that this structure confers. In addition, strains belonging to serotypes associated with human infections and characterized by pathogenic potential (serotype 4) are capable to persist within the processing plants forming biofilm and thus being a medical hazard.

Keywords: Listeria species, Buffalo, Cow, Virulence genes, Biofilm formation, Antibiotic resistance

\section{Background}

The Egyptians kept cattle [1] and milking pictures are as old as $6000 \mathrm{y}$ in Egypt and Iraq [2]. In Egypt, Livestock numbers in 2009 recorded 4.00 million buffaloes and 5.00 million cattle [3]. Cattle are one of the oldest domesticated animals. Their uses lies in transportation, as a food, and fiber for clothing and significant milk producers whose

\footnotetext{
*Correspondence: kamelia-osman@hotmail.com

'Department of Microbiology, Faculty of Veterinary Medicine, Cairo

University, PO Box 12211, Cairo, Egypt

Full list of author information is available at the end of the article
}

milk and milk products are an important component of the human diet globally.

Listeria spp. are microaerophilic, belonging to the Firmicutes phylum. Members of the Listeria genus are- $L$. monocytogenes, $L$. ivanovii, $L$. innocua, $L$. seeligeri, $L$. welshimeri, L. grayi, L. marthii and L. rocourtiae [4]. While L. monocytogenes is pathogenic for humans and animals, L. ivanovii is pathogenic to ruminants, and the other species are nonpathogenic [4].

Listeriosis affects domestic and wild animals, most often sheep and cattle, rarely goats, horses and poultry. 
Buffaloes and cows can excrete Listeria after miscarriage or during udder infections followed by mastitis through milk [5]. Cows with listeric mastitis may produce normal-appearing milk containing large numbers of bacteria [6]. This can be manifested in some cases for several years. Cow milk is mentioned as carrier of the fatal listeriosis [7]. Although listerial intramammary infections are rare, identification of infected animals is necessary for the dairy industry since contaminated milk and milk products have been involved in several outbreaks of listeriosis [7-10]. At the same time, serious concerns about the resistance of foodborne pathogens to antibiotics have been growing for a number of years at both national and international levels. Resistance of bacterial pathogens to antibiotics has increased worldwide, leading to treatment failures in human and animal infectious diseases [11].

In Egypt, listerial mastitis in buffalo and cow has not been previously perused. Therefore, we scrutinized carefully in the current study, the prevalence, isolation and identification of the different Listeria species as based on selective plating media, biochemical characterization, serological identification, their in vivo virulence potential, antibiotic resistance (ABR) profile and the connection between $A B R$, biofilm formation and virulenceassociated genes $(h l y \mathrm{~A}, p l c \mathrm{~B}, a c t \mathrm{~A}$ and $i a p)$.

\section{Methods}

The study was performed at the Department of Microbiology, Faculty of Veterinary Medicine, Cairo University, Egypt. This work was performed in accordance with the recommendations in the updated Guide for the Care and Use of Laboratory Animals published by the $\mathrm{Na}$ tional Institutes of Health (NRC, 2010). All procedures were approved by the Cairo University Ethical Committee in compliance with the United Kingdom (UK) Animals (scientific procedures) Act of 1986, all required approvals were obtained prior to the experiments.

\section{Sampling}

A total of 203 milk samples were collected from buffalo $(n=100)$ and cow $(n=103)$ from private dairy farms around Cairo. The milk and udder were never visibly abnormal throughout the course of the investigation. The animals had not been treated with an antibiotic for at least 30 days prior to collection. A composite milk sample (all four quarters in one collection vial to represent one udder) was taken after gentle stirring [12] under aseptic conditions for bacteriological examinations. A subsample of $15 \mathrm{ml}$ of milk, taken from the composite milk sample, was collected in sterile universal bottles. The milk samples were quickly transported to the laboratory under chilled conditions and stored at $4{ }^{\circ} \mathrm{C}$ till bacteriologically analyzed [13-15].

\section{Isolation and identification of Listeria species}

For the isolation and identification of Listeria species in the milk samples, the techniques previously adopted by Osman et al. $[14,15]$ were implemented.

\section{Primary selective enrichment}

The primary selective enrichment step involved a selective liquid median Half Fraser Enrichment Broth Antibiotic supplement CCFA (Oxoid; CM0895B and SR0166E). Twenty-five milliliter of each milk sample was added to $500 \mathrm{ml}$ of half Fraser broth, mixed and incubated at $30{ }^{\circ} \mathrm{C}$ for $48 \mathrm{~h}$.

\section{Secondary selective enrichment}

From the pre-enrichment culture (half Fraser broth), $0.1 \mathrm{ml}$ was transferred into $10 \mathrm{ml}$ of Fraser broth (Oxoid; CM0895B and SR0156E) and incubated at $35^{\circ} \mathrm{C}$ for $48 \mathrm{~h}$.

\section{Culture and strain characterization}

From the culture obtained in Fraser broth, a loopful of the culture was streaked onto PALCAM agar plates (Oxoid; CM0877B and SR0156E) and incubated at $37{ }^{\circ} \mathrm{C}$ for 24 to $48 \mathrm{~h}$. The plates were examined for the presence of characteristic colonies presumed to be Listeria. Identification of Listeria species on PALCAM agar plates was based on aesculin hydrolysis and mannitol fermentation. All Listeria species hydrolyse aesculin as evidenced by a blackening of the medium. Mannitol fermentation was demonstrated by a colour change in the colony and/ or surrounding medium from red or gray to yellow due to the production of acidic end products. The selectivity of the PALCAM medium is achieved through the presence of lithium chloride, polymixin B sulphate and acriflavine hydrochloride present in the medium base and ceftazidime provided by PALCAM antimicrobial supplement. These agents effectively suppress growth of most commonly occurring non-Listeria species of bacteria present in food samples.

\section{Confirmation of the isolates}

All strains were tested for purity, in addition to morphological and biochemical characteristics. Colonies suspected to be Listeria were transferred onto pre-dried plates of trytic soya yeast extract agar (TSYEA) (Difco, Bacton, USA) and incubated at $30{ }^{\circ} \mathrm{C}$ for 18 to $24 \mathrm{~h}$. Those putative Listeria colonies were characterized using Gram's staining, tumbling motility at $20-25{ }^{\circ} \mathrm{C}$, catalase test, Methyl Red - Voges Proskauer (MR-VP) reactions, characteristics of haemolysis on $5 \%$ sheep blood agar (SBA), carbohydrate utilization and CAMP test. The CAMP test was undertaken using S. aureus (ATCC 7494) and Rhodococcus equi (ATCC 6939) and E. coli (ATCC 25922). They were streaked in single lines across a sheep blood agar plate so that the two cultures were parallel and 
diametrically opposite. Test strains were then streaked at right angles and 1 to $2 \mathrm{~mm}$ apart to $S$. aureus and R. equi. Simultaneously, standard strain of $L$. monocytogenes (ATCC 7494) was streaked onto blood agar plates. The plates were then incubated at $37{ }^{\circ} \mathrm{C}$ for 18 to $24 \mathrm{~h}$. The test culture streaks were tested for enhanced $\beta$-hemolysis at both ends proximal to the reference cultures. The zone of enhanced $\beta$-hemolysis may resemble an arrowhead, circle or rectangle. The presence of this zone indicates a CAMP-positive reaction. Absence of enhanced $\beta$-hemolysis indicates a CAMP-negative reaction. L. monocytogenes and L. seeligeri are CAMP-positive to the Staphylococcus reference strain and CAMP-negative to $R$. equi. In contrast, $L$. ivanovii is CAMP-positive to the $R$. equi reference strain and CAMP-negative to the Staphylococcus reference strains. For the carbohydrate utilization test, isolated colonies from TSYEA were transferred into test tubes containing xylose, rhamnose and mannitol and incubated at $37^{\circ} \mathrm{C}$ for up to 5 days. Positive reactions were indicated by yellow color (acid formation) and occured mostly within 24 to $48 \mathrm{~h}$. In parallel, strains were identified using the $\mathrm{API}^{\circ}$ Listeria system (bioMe'rieux, Marcy l'Etoile, France) and the Oxoid Microbact ${ }^{\text {tx }}$ Listeria 12L (MB1128A). The Microbact ${ }^{\mathrm{mm}}$ Listeria 12L system is intended to be used for the identification of Listeria spp. isolated from the milk samples.

\section{Phosphatidylinositol-specific phospholipase C (PI-PLC) assay}

All the biochemically characterized Listeria isolates were assayed for PI-PLC activity [16]. In brief, the Listeria isolates were grown overnight on sheep blood agar (SBA) plates at $37^{\circ} \mathrm{C}$. The growth of each Listeria isolate harvested from the SBA plate was spot inoculated separately on tryptone soya yeast extract agar plates supplemented with $2.5 \mathrm{mM} \mathrm{CaCl}_{2}$ and $40 \mathrm{mM} \mathrm{MgSO}_{4}$ in a manner to get a clear visible bacterial growth of approximately $2 \mathrm{~mm}$ diameter following an incubation at $37^{\circ} \mathrm{C}$ for 24 to $48 \mathrm{~h}$. An overlay suspension was prepared and overlayed at a rate of $4 \mathrm{ml}$ per petridish $(9 \mathrm{~cm} \varnothing)$ onto the previously seeded colonies of Listeria isolates on TSYE. The plates were then incubated at $37^{\circ} \mathrm{C}$ and observed daily for turbid halos around colonies up to 5 days.

\section{DL-alanine-b-naphthylamide and D-alanine-p-nitroanilide hydrolysis tests}

The DL-alanine- $\beta$-naphthylamide $\mathrm{HCl}$ (DLABN) and Dalanine- $p$-nitroanilide (DAPN) tests were performed as described previously [17] in order to differentiate L. monocytogenes from other species of Listeria. Cultures were grown on TSA or blood agar for 18 to $24 \mathrm{~h}$ at $35^{\circ} \mathrm{C}$, and the majority of the growth was harvested with a sterile cotton swab into $1.0 \mathrm{ml}$ of sterile saline, and of this, $25-\mathrm{ml}$ aliquots were added to 96 -well microtiter plates. A $20 \mathrm{mM}$
DL-alanine- $\beta$-naphthylamide $\mathrm{HCl}$ solution was prepared in sterile $0.05 \mathrm{M}$ Tris- $\mathrm{HCl}$ buffer ( $\mathrm{pH} 7.0)$. A $20 \mathrm{mM}$ Dalanine- $p$-nitroanilide (DAPN) solution was similarly prepared. Fast violet B solution (FVB) was prepared by dissolving a 12.0-mg capsule in $5 \mathrm{ml}$ of sterile distilled water. Just prior to the test, the DLABN or the DAPN stock was diluted in $0.05 \mathrm{M}$ Tris- $\mathrm{HCl}(\mathrm{pH} 7.0)$ to give a $15 \mathrm{mM}$ solution, and $50 \mathrm{ml}$ was added to $25 \mathrm{ml}$ of the bacterial suspensions in the wells of the sterile 96-well microtiter plate. Negative controls contained $25 \mathrm{ml}$ of saline in place of the bacterial suspension. The plate was covered with stretch plastic and incubated in the dark at $37{ }^{\circ} \mathrm{C}$ for $4 \mathrm{~h}$ for DLABN or overnight for DAPN. The cover was removed, and $50 \mathrm{ml}$ of FVB solution was added to the colorless DLABN tests. Free $\beta$-naphthylamine was detected by observing the deep yellow-orange complex, which developed within 5 min. Hydrolysis of the DAPN was seen by the liberation of the intense yellow $p$-nitrophenol.

The presumptive colonies of Listeria (at least three per plate) were further confirmed by various methods as described below.

\section{Serotype profile}

Serotyping was carried out on L. monocytogenes strains using commercial specific antisera (Behringwerke AG) against the serovars 1 and 4, following the manufacturer's instructions.

\section{Antibiogram profile}

The 17 purified isolates were tested by the standard disc diffusion method [18] and were subjected to a susceptibility panel of 28 antibiotics (Oxoid) belonging to 11 drug classes. Isolates were cultured in trypticase-soy broth (TSB) supplemented with $0.6 \%$ yeast extract, and transferred to Mueller-Hinton agar (Oxoid). The plates were incubated at $37{ }^{\circ} \mathrm{C}$ for $48 \mathrm{~h}$. Antimicrobials were selected for testing based on the licensing for mastitis treatment in cattle, use in human medicine and potential resistant-determinant phenotypes located on genetic mobile elements (TET and ERY) [19, 20]. Resistance was determined by measurement of inhibition of growth around the antimicrobial disk according to the zone diameter interpretative standards of CLSI [18] or according to the antimicrobials manufacturers' instructions: Penicillins: Ampicillin $(25 \mu \mathrm{g})$, Penicillin G (10 IU), Amoxicillin/clavulanic acid $(10 \mu \mathrm{g})$, Cloxacillin $(5 \mu \mathrm{g})$, Oxacillin $(1 \mu \mathrm{g})$, Amoxicillin $(25 \mu \mathrm{g})$; Fluorquinolones: Ofloxacin $(10 \mu \mathrm{g})$, Enrofloxacin $(10 \mu \mathrm{g})$, Ciprofloxacin $(5 \mu \mathrm{g})$, Flumequine $(30 \mu \mathrm{g})$, Pefloxacin $(30 \mu \mathrm{g})$; Aminoglycosides: Amikacin $(30 \mu \mathrm{g})$, Gentamicin $(10 \mu \mathrm{g})$, Kanamycin $(30 \mu \mathrm{g})$, Neomycin $(10 \mu \mathrm{g})$, Streptomycin $(10 \mu \mathrm{g})$; Cephalosporins: Cefotaxime $(30 \mu \mathrm{g})$, Cephalothin $(30 \mu \mathrm{g})$; Lincosamides: Lincomycin $(2 \mu \mathrm{g})$, Clindamycin $(2 \mu \mathrm{g})$; Phenicol: 
Chloramphenicol (30 $\mu \mathrm{g})$; Tetracycline: Tetracycline (30 $\mu \mathrm{g})$; Glycopeptide: Vancomycin $(30 \mu \mathrm{g})$; Rifamycin: Rifampicin $(5 \mu \mathrm{g})$; Macrolide: Erythromycin $(15 \mu \mathrm{g})$, Spiramycin $(100 \mu \mathrm{g})$; Polypeptides: Bacitracin (10 units); Sulfonamide: Trimethoprim-sulfamathoxazole 1:19 $(25 \mu \mathrm{g})$.

The isolates were further tested for their pathogenicity. The classical tests for Listeria pathogenicity are the Anton conjunctivitis test (rabbits), inoculation of mice, and inoculation of embryonated eggs [13].

\section{Mice inoculation test}

The pathogenicity testing of the Listeria isolates by mice inoculation test was performed according to the method described by Menudier et al. [21]. Briefly, the test isolates of Listeria were grown on brain heart infusion agar (BHI) slants at $37{ }^{\circ} \mathrm{C}$ for $24 \mathrm{~h}$. Female BALB/c mice weighing 18-20 g were housed five per cage and allowed to acclimatize for one week. They were inoculated intraperitoneally with $0.1 \mathrm{ml}$ of inoculum having approximately $10^{9} \mathrm{CFU}$ of each Listeria isolate $/ \mathrm{ml}$. One group of five mice was injected with $0.1 \mathrm{ml}$ sterile saline, and one group of three mice was not injected. Observations were made daily and mortalities recorded until all of the mice inoculated with virulent strain EGD (NCTC7973) had died. One dead mouse per group was necropsied and spleen recovered for listerial isolation in BHI agar and subsequent PCR confirmation. On the 15th day after inoculation, all surviving mice were euthanized, and one mouse per group was necropsied and the livers and spleens were removed and homogenized, and the bacterial load was enumerated by colony counting [22] for Listeria.

The CFUs for individual $L$. monocytogenes strains were obtained by plating aliquots of diluted $L$. monocytogenes suspensions (at $10^{9}$ ) on BHI agar. After overnight incubation, the resultant colonies were enumerated, and the CFUs in the original inoculations calculated. The $50 \%$ lethal dose $\left(\mathrm{LD}_{50}\right)$ for each strain was then determined on the basis of mouse mortality data and CFU. The relative virulence (\%) was calculated by dividing the number of dead mice recorded with the number of mice tested per strain using the mortality data of the control strain L. monocytogenes EGD (NCTC7973) as reference points.

\section{Chick embryo inoculation test}

The pathogenicity of Listeria isolates was assessed by chick embryo inoculation test as per the method described by Olier et al. [23]. Briefly, the blood vessel-free surface of chorioallantoic membrane of 60 pre-candled 12-day old embryonated chicken eggs were inoculated with $0.1 \mathrm{ml}$ of a $10^{-4}$ dilution of the $\mathrm{McF} \# 1$ equivalent test culture in Tryptose phosphate broth (TPB). The inoculated eggs along with the controls (eggs inoculated with $0.1 \mathrm{ml}$ of sterile TPB) were incubated horizontally at $37{ }^{\circ} \mathrm{C}$ for 5 days and were examined twice a day by transillumination for embryo death, if any. Any test isolate causing embryo mortality after $24 \mathrm{~h}$ of inoculation was considered as pathogenic.

\section{Anton's eye test}

An experimental keratoconjunctivitis test (Anton's eye test) was performed in rabbits by inoculating a drop of live bacterial suspension of Listeria species onto the eye. Only L. monocytogenes causes purulent keratoconjuctivitis within 24-36 h of inoculation [24] and usually heals spontaneously [25].

\section{Vero cell cytotoxicity assay}

The cytotoxicity assay on Vero cells was carried out according to Raja et al. [26] obtained from American Type Culture Collection, Rockville, Madison, USA, was used. Cell Free Culture Supernatants (CFCS) of the 17Listeria isolates were prepared. Each bacterial strain was grown in BHI broth for $24 \mathrm{~h}$ at $37^{\circ} \mathrm{C}$. After incubation, an inoculum containing $5 \times 10^{7} \mathrm{CFU} / \mathrm{ml}$ was taken from which $100 \mu \mathrm{l}$ was added to the wells containing Vero cells. The bacterial cells were allowed to infect the epithelial cells for $30 \mathrm{~min}$ to $12 \mathrm{~h}$ at $37^{\circ} \mathrm{C}$. A control set up was maintained where the cell lines were not treated with the pathogen. Live cells were taken out and the cytological changes were observed using an inverted microscope. The Vero cell-line was maintained at $37{ }^{\circ} \mathrm{C}$ (4-6\% $\mathrm{CO}_{2}$ and $85 \%$ humidity) in a Vero medium, which was Dulbecco's minimal essential medium with Earle's salts, $1 \%$ sodium pyruvate, $20 \%$ fetal bovine serum, $1.0 \%$ nonessential amino acids, $1.5 \mathrm{~g} / \mathrm{L}$ sodium bicarbonate, and, when appropriate, penicillin $\mathrm{G}$ and streptomycin (each at $100 \mu \mathrm{g} / \mathrm{mL}$ ). All invasion assays were performed at $37{ }^{\circ} \mathrm{C}$ as previously described (Raja et al., 2010). Briefly, $48 \mathrm{~h}$ before the assay, Vero cells were seeded into 24-well tissue culture plates at a density of $5 \times 10^{4}$ cells/well in the Vero medium without antibiotics. For infection, $\sim 2 \times 10^{7} \mathrm{CFU}$ of each Listeria species isolated were added to each well (representing a multiplicity of infection of $\sim 200$ ). All inocula were enumerated on BHI agar plates. Thirty minutes postinfection, the Vero monolayers were washed three times with PBS to remove any unassociated Listeria species, and the medium was replaced with a fresh Vero medium. Forty-five minutes after infection, the medium was replaced with the Vero medium plus $150 \mu \mathrm{g} / \mathrm{mL}$ gentamycin to kill any extracellular Listeria species. At 90 min postinfection, Vero cells were washed three times with PBS and lysed with ice-cold distilled water. Intracellular Listeria species were enumerated by plating the appropriate dilutions of the Vero lysate on BHI agar. At least three independent trials of the invasion assays were performed with duplicate wells tested for each treatment in each replicate. 


\section{Biofilm formation \\ Glass test tubes}

Biofilm formation assay was determined according to Giacaman et al. [27] by Christensen's tube method. Each Listeria strain was inoculated with loopful of microorganism from overnight culture plates in brain heart infusion broth $(10 \mathrm{ml})$ and incubated for $24 \mathrm{~h}$ at $37^{\circ} \mathrm{C}$. The cells were incubated in the test tubes without shaking. The tubes were decanted and washed with PBS $(\mathrm{pH} 7.3)$ and dried. Dried tubes were stained with crystal violet $(0.1 \%)$. Excess stain was removed and tubes were washed with deionized water. Tubes were than dried in inverted position and observed for slime layer formation. Biofilm formation was considered positive when a visible film lined the wall and bottom of the tube. Ring formation at the liquid interface was not indicative of biofilm formation. All the strains were tested in triplicate. Tubes were examined and the amount of biofilm formation was scored as 0 -absent, 1 -weak, 2-moderate or 3-strong.

\section{Microtiter plate assay}

Listeria species isolates were recovered from $-80{ }^{\circ} \mathrm{C}$ glycerol stocks onto tryptic soy agar and were stored at $4{ }^{\circ} \mathrm{C}$. Isolated colonies were used to inoculate $3 \mathrm{ml}$ of tryptic soy broth enriched with $0.6 \%$ yeast extract (TSBYE) in sterile 15 - by $100-\mathrm{mm}$ glass culture tubes and were incubated for $24 \mathrm{~h}$ at $37{ }^{\circ} \mathrm{C}$. According to the procedure of Borucki et al. [28], one milliliter of a 1:40 dilution of each overnight culture was prepared in freshly made Modified Welshimer's broth (MWB) and was vortexed for $5 \mathrm{~s}$. One hundred microliters of this dilution was then used to inoculate eight separate wells of a presterilized polyvinyl chloride (PVC) microtiter plate, and eight wells of MWB media were included as a control. The plates were incubated for $40 \mathrm{~h}$ at $30^{\circ} \mathrm{C}$. After $40 \mathrm{~h}$ the liquid from each of the wells was removed, and unattached cells were removed by rinsing three times in $150 \mu \mathrm{l}$ of sterile water. Biofilms were stained by adding $50 \mu \mathrm{l}$ of a $0.1 \%$ crystal violet solution to each well and incubating for $45 \mathrm{~min}$ at room temperature. Unbound dye was removed by rinsing three times in $150 \mu \mathrm{l}$ of sterile water. The crystal violet was solubilized by adding $200 \mu \mathrm{l}$ of $95 \%$ ethanol and incubating at $4{ }^{\circ} \mathrm{C}$ for $30 \mathrm{~min}$. The contents of each well $(100 \mu \mathrm{l})$ were then transferred to a sterile polystyrene microtiter plate, and the optical density at $595 \mathrm{~nm}\left(\mathrm{OD}_{595}\right)$ of each well was measured in a microplate reader.

\section{Molecular identification DNA extraction}

Freshly grown typical Listeria-like colonies (black colonies) were collected from the surfaces of Palcam plates and boiled in $400 \mu \mathrm{l}$ of $1 \times$ Tris-EDTA buffer (pH 8.0) (approximately $10^{8}$ cells $/ \mathrm{ml}$ ) boiled for $10 \mathrm{~min}$ and centrifuged at
$14,000 \mathrm{rpm}$ for $10 \mathrm{~min}$ to remove denatured proteins and bacterial membranes; $2 \mu \mathrm{l}$ of the supernatant was used as template for the PCR reaction.

\section{PCR detection for the genus Listeria}

Listeria was distinguished on the basis of the $16 \mathrm{~S}$ rRNA [29] that can be revealed by PCR (forward primer 5CAG-CMG-CCG-CGG-TAA-TWC-3 where M denotes $A$ or $C$, and $W$ denotes $A$ or $T$ and reverse primer 5CTC-CAT-AAA-GGT-GAC-CCT-3) to amplify the 938bp fragment. Amplification was performed with a volume of $50 \mu \mathrm{l}$ containing $10 \mu \mathrm{l}(200 \mathrm{ng})$ of extracted DNA template from bacterial cultures, $5 \mu \mathrm{l} 10 \times$ PCR buffer, $0.375 \mu \mathrm{l} \mathrm{MgCl}_{2}(1.5 \mathrm{mM}), \quad 1.25 \mu \mathrm{l}$ dNTPs $(250 \mu \mathrm{M}), 0.25 \mu \mathrm{l}$ (1.25 Unit) Ampli Taq DNA polymerase, $0.25 \mu \mathrm{l}(0.5 \mu \mathrm{M})$ from each primer pairs. The volume of the reaction mixture was completed to $50 \mu \mathrm{l}$ using DDW. The reaction mixture was overlaid with mineral oil, and the tubes were placed in a DNA thermal cycler (Perkin-Elmer Cetus, Norwalk, Conn.). The samples were subjected to an initial denaturation step of $94{ }^{\circ} \mathrm{C}$ for $4 \mathrm{~min}$, followed by 25 amplification cycles of $1 \mathrm{~min}$ at $94{ }^{\circ} \mathrm{C}$ (denaturation), $1 \mathrm{~min}$ at $60^{\circ} \mathrm{C}$ (primer annealing), and $1 \mathrm{~min}$ at $72{ }^{\circ} \mathrm{C}$ (primer extension) followed by a final extension step of $72{ }^{\circ} \mathrm{C}$ for $5 \mathrm{~min}$. PCR reaction products were separated on $1.5 \%$ agarose gels, stained with ethidium bromide and visualized. L. monocytogenes strain (ATCC 7494) and an E. coli strain (ATCC 25922) were included as positive and negative controls respectively.

\section{PCR detection of virulence genes among Listeria species}

The 17 Listeria isolates were screened by PCR for the presence of the virulence genes using the primers: hlyA (for.) 5'-GCA GTT GCA AGC GCT TGG AGT GAA-3', (rev.) 5' - GCA ACG TAT CCT CCA GAG TGA TCG-3' [30] to amplify the 456-bp fragment; plcB (for.) 5 '-CTG CTT GAG CGT TCA TGTCTC ATC CCC C-3', (rev.) 5' -ATG GGT TTC ACT CTCCTT CTA C-3' [15] to amplify the 1484-bp fragment; actA (for.) 5'-CGC CGC GGA AAT TAA AAA AAG A-3', (rev.) 5' - ACG AAG GAA CCG GGCTGC TAG - 3' [31] to amplify the 839-bp fragment; and Iap (for.) 5'-ACA AGC TGC ACC TGT TGC AG-3', (rev.) 5' -TGACAG CGT GTG TAG TAG CA-3' [32] to amplify the 131-bp fragment. Amplification was performed with a volume of $50 \mu \mathrm{l}$ containing $10 \mu \mathrm{l}$ (30-50 ng) of extracted DNA template from bacterial cultures, $5 \mu \mathrm{l} 10 \times$ PCR buffer, $5 \mu \mathrm{l} \mathrm{MgCl}$ (25 mM), $4 \mu \mathrm{l}$ dNTPs (25 mM), $1.54 \mu \mathrm{l}(2.5 \mathrm{U} / \mathrm{ul})$ Ampli Taq DNA polymerase, $2 \mu \mathrm{l}$ $(0.5 \mu \mathrm{M})$ from each primer pairs. The volume of the reaction mixture was completed to $50 \mu \mathrm{l}$ using Double Distilled Water (DDW). The reaction mixture was overlaid with mineral oil, and the tubes were placed in a DNA thermal cycler (Perkin-Elmer Cetus, Norwalk, Conn.). The samples were subjected to an initial denaturation step of $95{ }^{\circ} \mathrm{C}$ for 
2 min, followed by 35 amplification cycles of $15 \mathrm{~s}$ at $95{ }^{\circ} \mathrm{C}$ (denaturation), $30 \mathrm{~s}$ at $60{ }^{\circ} \mathrm{C}$ (annealing), and $90 \mathrm{~s}$ at $72{ }^{\circ} \mathrm{C}$ (primer extension) followed by a final extension step of $72{ }^{\circ} \mathrm{C}$ for $10 \mathrm{~min}$. Visualization of the PCR products was carried out as previously indicated.

\section{Results}

\section{Prevalence of Listeria}

A total of 203 milk samples collected from buffaloes (100) and cows (103) were screened for Listeria species (Table 1). The microbiological analysis revealed 17 isolates resembling Listeria spp. Three isolates were identified as $L$. monocytogenes. The remaining 14 listeriae were considered Listeria spp. The overall prevalences of Listeria spp. and L. monocytogenes were $6.9 \%(14 / 203)$ and $1.4 \%(3 /$ 203), respectively. The prevalence of Listeria species was found to be, L. innocua (2/203; $1.0 \%)$, L. welshimeri (5/ 203; $2.5 \%)$, L. seeligeri $(4 / 203 ; 2.0 \%)$ and L. grayi $(3 / 203$; $1.5 \%)$ of the isolates. L. monocytogenes was detected in udder milk samples at prevalences of buffalo $1 \%(1 / 100)$ and $2 \%$ for cow $(2 / 103)$.

The three L. monocytogenes isolated from 203 milk samples $(1.5 \%)$ were serologically typed as follows: The identified $L$. monocytogenes serotypes were Type 1 and this was isolated from the buffalo milk samples while Type 4 L. monocytogenes was isolated from samples obtained from cow milk samples only.

\section{Pathogenicity testing}

The pathogenicity testing of the 17 Listeria isolates via the PI-PLC, DLABN and DAPN assays, as well as in vivo tests, namely chick embryo, mice inoculation tests, Anton's eye test and Vero cytotoxicity assay, indicated that, the three hemolytic $L$. monocytogenes isolates were found to be pathogenic (Table 1). Spleens from mice that died during the challenge contained viable $L$. monocytogenes that was recovered on BHI agar and confirmed by PCR. On the other hand, spleens from mice that survived the Listeria spp. challenge by day 15 had no viable Listeria detectable on BHI agar. All other Listeria spp. isolates were non-pathogenic (Table 1). The three hemolytic isolates of $L$. monocytogenes showed the characteristic enhancement of hemolytic zone with S. aureus (Table 1).

\section{Biofilm formation}

\section{Biofilm formation by Listeria strains in glass test tubes}

The results of adherence assay to test glass tube assessed by $0.1 \%$ Crystal Violet stain showed that the three isolated L. monocytogenes isolates (buffalo and cow) were able to strongly form biofilm on glass surface while the isolated strain from buffalo was moderately adherent (Tables 1 and 2). The L. innocua, L. welshimeri, L. seeligari and $L$. grayi were variable in their results (Tables 1 and 2).

\section{Quantitative biofilm formation by Listeria strains on polystyrene}

The $17 \mathrm{~L}$. monocytogenes strains were screened for their adherence to polystyrene 96 well microtiter plates at different degrees. The results showed that $L$. monocytogenes was able to form biofilm on polystyrene $\left(\mathrm{OD}_{570}>1\right)$ and was considered as very strong (Tables 1 and 2). The same strong affinity was also observed with $L$. innocua, L. welshimeri, L. seeligari and L. grayi (Tables 1 and 2).

\section{Distribution of resistance to individual antimicrobial agents}

In this study, the susceptibility of isolates varied between 84.2 and $100 \%$ for most antimicrobials. The major resistance phenotypes was found to be against: cloxacillin, oxacillin, flumequine, neomycin, cefotaxime, cephalothin, lincomycin, clindamycin, chloramphenicol. On the basis of criteria established by the CLSI for Staphylococcus species and Enterococcus species, the L. monocytogenes isolated from the buffalo and cow were resistant to cloxacillin, oxacillin, pefloxacin, flumoquine, cephalosporines, bacitracin, lincomycin and clindamycin. In addition, the L. monocytogenes isolated from the buffalo were also resistant to chloramphenicol. On the other hand the $L$. monocytogenes isolated from cow showed resistance for trimethoprim/sulfamathoxazole (Table 2). The other Listeria species were diverse in their resistance profile. L. innocua isolated from the buffalo and cow were resistant to penicillin, cloxacillins, oxacillins, pefloxacin, flumequine, lincomycins, clindamycin and cephalosporins. In addition, the L. innocua isolated from bufflo raw milk showed an additional resistance to streptomycins and trimethoprime/sulfamathoxazole. Also, L. seelegeri isolates were resistant to cloxacillins, oxacillins, pefloxacin, flumequine, lincomycins and cephalosporins. The $L$. welshermeri isolates were resistant to penicillins, cloxacillins, oxacillins, amoxicillin, ampicillin, amoxicillin, clavulinic acid, pefloxacin, ciprofloxacin, flumequine, lincomycins, and cephalosporins. L. grayi isolates were resistant to cloxacillins, oxacillins, pefloxacin, flumequine, lincomycins, clindamycin, cephalosporins and rifampicin.

\section{Distribution of the virulence genes}

For virulotyping analysis, the isolates were screened for the presence of four virulence genes ( $h l y, p l c$, act and iap) by conventional PCR which showed that all genes were present in $L$. monocytogenes while absent in other species except $L$. seelegeri which carried the hly gene (Table 2).

\section{Association between antimicrobial resistance, biofilm, serotype and virulence genes}

The relationship between antimicrobial resistance, $L$ monocytogenes serotypes, affinity for biofilm formation and virulence revealed a strong affinity of the $L$. monocytogenes $1 / 2 \mathrm{a}$ (Lineage II) and 4a and 4c (Lineage III) to form a biofilm 
Table 1 Pathogenicity profiles of Listeria species isolated from buffalo and cow milk

\begin{tabular}{|c|c|c|c|c|c|c|c|c|c|c|c|c|}
\hline \multirow{3}{*}{$\begin{array}{l}\text { Source of milk } \\
\text { samples }\end{array}$} & \multirow[t]{3}{*}{ Listeria species } & \multirow[t]{3}{*}{ Serotype } & \multicolumn{9}{|c|}{ Pathogenicity profile } & \multirow[b]{3}{*}{ Christensen's tube } \\
\hline & & & \multirow{2}{*}{$\begin{array}{l}\text { CAMP (+/-) } \\
\text { with S/R }\end{array}$} & \multirow[t]{2}{*}{ PI-PLC } & \multirow[t]{2}{*}{ DLABN } & \multirow[t]{2}{*}{ DAPN } & \multirow{2}{*}{$\begin{array}{l}\text { Anton's eye } \\
\text { test }\end{array}$} & \multirow[t]{2}{*}{ Mice lethality } & \multirow{2}{*}{$\begin{array}{l}\text { Chick-embryo } \\
\text { lethality }\end{array}$} & \multirow{2}{*}{$\begin{array}{l}\text { Vero cell } \\
\text { ingestion assay }\end{array}$} & Biofilm & \\
\hline & & & & & & & & & & & Microtiter plate assay & \\
\hline (ATCC 7494) & monocytogenes & 4 & $+/-$ & + & - & - & + & + & + & ++ & Strong (O.D. $=0.158)$ & Strong \\
\hline \multirow[t]{8}{*}{ Buffalo } & monocytogenes & 1 & $+/+$ & + & - & - & + & + & + & ++ & Strong (O.D. $=0.148)$ & Moderate \\
\hline & innocua & & - & - & + & + & - & - & - & - & Strong (O.D. $=0.167)$ & Strong \\
\hline & seelegeri & & - & - & + & + & - & - & - & - & Strong (O.D. $=0.144)$ & Moderate \\
\hline & seelegeri & & - & - & + & + & - & - & - & - & Strong (O.D. $=0.157)$ & Moderate \\
\hline & welshemeri & & - & - & + & + & - & - & - & - & Strong (O.D. $=0.145)$ & Weak \\
\hline & welshemeri & & - & - & + & + & - & - & - & - & Strong (O.D. $=0.141)$ & Weak \\
\hline & grayi & & - & - & + & + & - & - & - & - & Weak (O.D. = 0.0995) & Moderate \\
\hline & grayi & & - & - & + & + & - & - & - & - & Strong (O.D. $=0.134)$ & Moderate \\
\hline \multirow[t]{8}{*}{ Cow } & monocytogenes & 4 & $+/-$ & + & - & - & + & + & + & ++ & Strong (O.D. $=0.123)$ & Strong \\
\hline & innocua & & - & - & + & + & - & - & - & - & Strong (O.D. $=0.125)$ & Strong \\
\hline & seelegeri & & - & - & + & + & - & - & - & - & Weak (O.D. $=0.074)$ & Moderate \\
\hline & seelegeri & & - & - & + & + & - & - & - & - & Very Strong (O.D. $=0.231)$ & Moderate \\
\hline & welshemeri & & - & - & + & + & - & - & - & - & Strong (O.D. $=0.128)$ & Moderate \\
\hline & welshemeri & & - & - & + & + & - & - & - & - & Strong (O.D. $=0.121)$ & Moderate \\
\hline & welshemeri & & - & - & + & + & - & - & - & - & Strong (O.D. $=0.117)$ & Moderate \\
\hline & L. grayi & & - & - & + & + & - & - & - & - & Strong (O.D. $=0.173)$ & Weak \\
\hline
\end{tabular}

CAMP Christie, Atkins, Munch-Petersen test, S/R Staphylococcus aureus/Rhodococcus equi, PI-PLC phosphatidylinositol-specific phospholipase C, DLABN DL-alanine-b-naphthylamide HCI, DAPN D-alanine-p-nitroanilide, O.D. Optical Density, O.D. $595<0.1=$ Weak; O.D. $595 \leq 0.1=$ Strong; O.D. $595>1=$ Very Strong 
Table 2 A comparative layout of the diversity in listerial species isolated from buffaloes and cows and their antibiotic resistance phenotype in relation to their affinity to biofilm formation and virulence genes

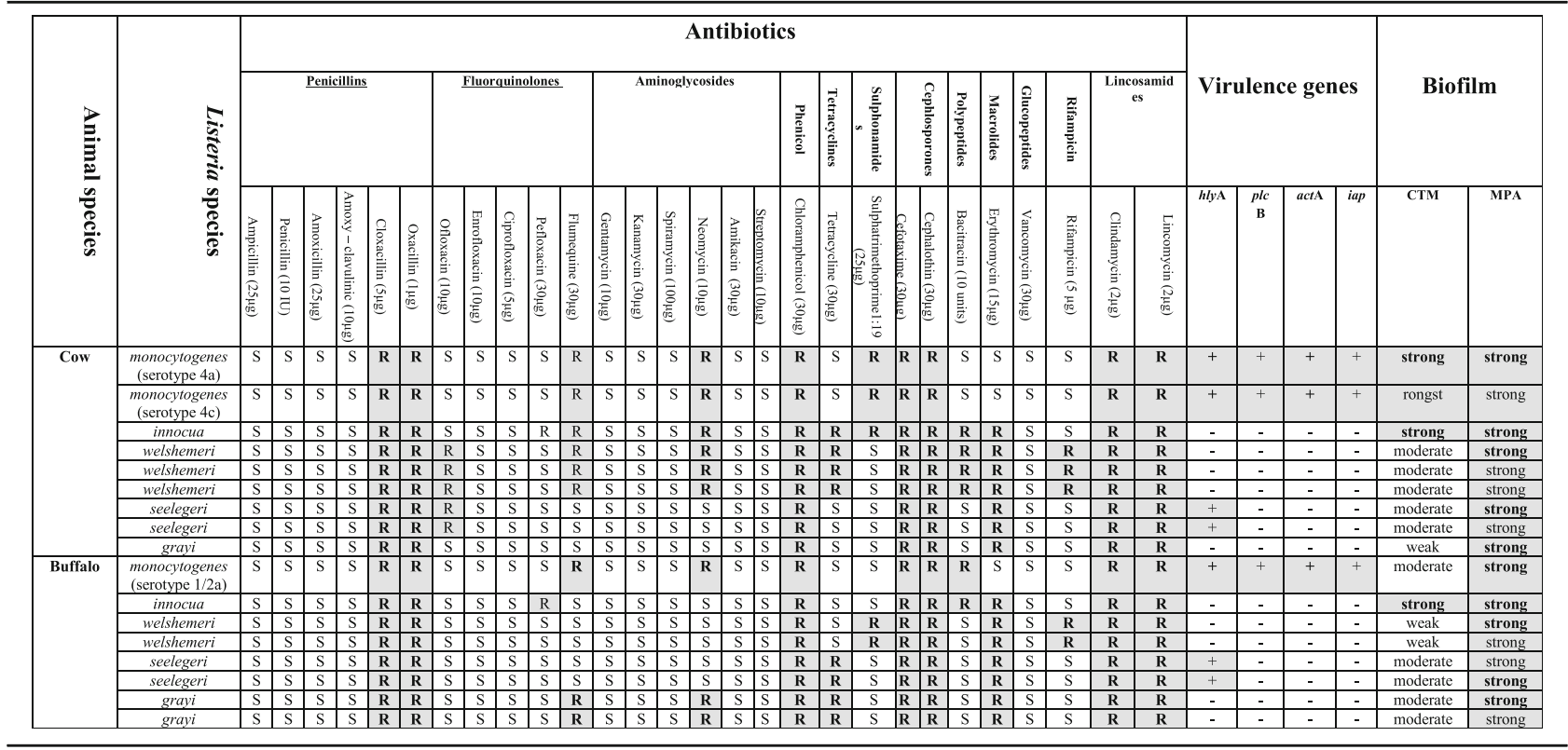

CTM Christensen's tube method, MPA Microtiter plate assay, resistant, $\boldsymbol{S}$ susceptible, Zone diameter, $\leq 18 \mathrm{~mm}$, Resistant; $\geq 25 \mathrm{~mm}$ Susceptible

on the abiotic surfaces, polystyrene and glass, in addition to their encoding of the virulence genes $(p l c \mathrm{~B}, a c t \mathrm{~A}, h l y \mathrm{~A}$ and iap) (Table 2). Also, irrespective of the Listeria species investigated, $85.7 \%(12 / 14)$ of the non-L. monocytogenes had a strong affinity to form a biofilm on the abiotic polystyrene surface while, only $14.3 \%(2 / 14)$ of these same species had the same affinity on the glass surface.

\section{Multiple resistance patterns and distribution}

The three L. monocytogenes and 14 Listeria species displayed multidrug resistance to more than three antibiotics. Their multidrug-resistance patterns are displayed in Table 3. It was noticed that a combination of $14 / 28$ antibiotics were distributed in two forms: cloxacillin/oxacillin/ flumequine/pefloxacin/neomycin/cefotaxime/cephalothin/ lincomycin/clindamycin/chloramphenicol/tetracycline/ erythromycin/bacitracin/trimethoprim-sulfamathoxazole and another combination of cloxacillin/oxacillin/ofloxacin/ flumequine/neomycin/cefotaxime/cephalothin/lincomycin/ clindamycin/chloramphenicol/tetracycline/rifampicin/ erythromycin/bacitracin were the most prevalent and each combination represented 10 classes.

The two L. monocytogenes isolated from the cow exhibited an antibiotic combination of cloxacillin/oxacillin/ flumequine/neomycin/cefotaxime/cephalothin/chloramph enicol/lincomycin/clindamycin/trimethoprim sulfamat hoxazole $(10 / 28)$ representing seven classes. On the other hand, the isolated L. monocytogenes isolated from the buffalo was resistant to the cloxacillin/oxacillin/ flumequine/neomycin/cefotaxime/cephalothin/lincomycin/ clindamycin/chloramphenicol combination (9/28) representing six classes.

\section{Discussion}

Food commodities which can often contain L. monocytogenes embrace a large diversification of prepared to-eat or raw foods, equivalent to raw milk or meat and their products, raw mushrooms, soft cheese and seafood [33].

It was essential to distinguish between Listeria species and the phylogenetically related Brochothrix, which is considered to be of relevance in food spoilage and distinguishable from Listeria by being non-motile, nonpathogenic and inability to grow at $35{ }^{\circ} \mathrm{C}$ [13]. Our biochemical reactions were consistent with the previous recorded findings of Hitchins and Jinneman, (2013) where L. monocytogenes and L. seeligeri were hemolytic in sheep blood. The failure of L. monocytogenes in the utilization of xylose and ability to utilize rhamnose was also observed by the non-hemolytic species L. innocua and $L$. grayi although they were negative in the CAMP test [13]. It should be emphasized that, L. innocua sometimes is unable to utilize rhamnose [13] to be interestingly observed with $L$. welshimeri and $L$. grayi. The in vivo pathogenicity assays, (chick embryo, mice inoculation tests, Anton's eye test and Vero cytotoxicity), confirmed the pathogenicity of the three $L$. monocytogenes isolates and the non-pathogenic nature of the other Listeria species (L. innocua, L. welshimeri, L. seeligeri and L. grayi). 
Table 3 Antibiotic resistance phenotype combination patterns of different Listeria species in cow and buffalo animals

\begin{tabular}{|c|c|c|c|c|c|c|}
\hline Source of milk & Listeria species & $\begin{array}{l}\text { Number of } \\
\text { Listeria species }\end{array}$ & Patterns of antibiotic combinations & $\begin{array}{l}\text { Number of } \\
\text { combination } \\
\text { patterns }\end{array}$ & $\begin{array}{l}\text { Number of } \\
\text { antibiotics }\end{array}$ & $\begin{array}{l}\text { Number of } \\
\text { antibiotic classes }\end{array}$ \\
\hline \multicolumn{7}{|l|}{ Cow } \\
\hline & $\begin{array}{l}\text { monocytogenes } \\
\text { (serotypes } 4 a \text { and } 4 c\end{array}$ & 2 & $\begin{array}{l}\text { cloxacillin/oxacillin/flumequine/neomycin/cefotaxime/cephalothin/chloramphenicol/lincomycin/ } \\
\text { clindamycin/trimethoprim-sulfamathoxazole }\end{array}$ & 5 & $10 / 28$ & 7 \\
\hline & innocua & 1 & $\begin{array}{l}\text { cloxacillin/oxacillin/flumequine/pefloxacin/neomycin/cefotaxime/cephalothin/ } \\
\text { lincomycin/clindamycin/ } \\
\text { chloramphenicol/tetracycline/erythromycin/bacitracin/trimethoprim-sulfamathoxazole }\end{array}$ & & $14 / 28$ & 10 \\
\hline & welshemeri & 3 & $\begin{array}{l}\text { cloxacillin/oxacillin/ofloxacin/flumequine/neomycin/cefotaxime/cephalothin/lincomycin/ } \\
\text { clindamycin/chloramphenicol/tetracycline/rifampicin/erythromycin/bacitracin }\end{array}$ & & $14 / 28$ & 10 \\
\hline & seelegeri & 2 & $\begin{array}{l}\text { cloxacillin/oxacillin/ofloxacin/cefotaxime/cephalothin/lincomycin/clindamycin/chloramphenicol/ } \\
\text { erythromycin }\end{array}$ & & $9 / 28$ & 6 \\
\hline & grayi & 1 & $\begin{array}{l}\text { cloxacillin/oxacillin/cefotaxime/cephalothin/lincomycin/clindamycin/ } \\
\text { chloramphenicol/erythromycin }\end{array}$ & & $8 / 28$ & 6 \\
\hline \multicolumn{7}{|l|}{ Buffalo } \\
\hline & $\begin{array}{l}\text { monocytogenes } \\
\text { (serotype } 1 / 2 a \text { ) }\end{array}$ & 1 & $\begin{array}{l}\text { cloxacillin/oxacillin/flumequine/neomycin/cefotaxime/cephalothin/lincomycin/ } \\
\text { clindamycin/chloramphenicol }\end{array}$ & 5 & $9 / 28$ & 6 \\
\hline & innocua & 1 & $\begin{array}{l}\text { cloxacillin/oxacillin/pefloxacin/cefotaxime/cephalothin/lincomycin/clindamycin/ } \\
\text { chloramphenicol/erythromycin/bacitracin }\end{array}$ & & $10 / 28$ & 7 \\
\hline & welshemeri & 2 & $\begin{array}{l}\text { cloxacillin/oxacillin/cefotaxime/cephalothin/lincomycin/clindamycin/chloramphenicol/ } \\
\text { rifampicin/erythromycin/trimethoprim-sulfamathoxazole }\end{array}$ & & $10 / 28$ & 7 \\
\hline & seelegeri & 2 & $\begin{array}{l}\text { cloxacillin/oxacillin/cefotaxime/cephalothin/lincomycin/clindamycin/chloramphenicol/ } \\
\text { tetracycline/erythromycin }\end{array}$ & & $9 / 28$ & 6 \\
\hline & grayi & 2 & $\begin{array}{l}\text { cloxacillin/oxacillin/flumequine/neomycin/cefotaxime/cephalothin/lincomycin/clindamycin/ } \\
\text { chloramphenicol/tetracycline/erythromycin }\end{array}$ & & $11 / 28$ & 8 \\
\hline
\end{tabular}


Consequently, moving to the stage of sero- and genotyping of Listeria isolates becomes relevant. The main virulence determinant, Listeriolysin O (LLO), prevails in $L$. monocytogenes coded by the $h l y \mathrm{~A}$ gene. According to the hlyA gene of L. monocytogenes the PCR assay could detect 2 cells in milk [34]. Fortunately, L. ivanovii was not isolated in our study although being incriminated to be a predominant animal pathogen affecting ruminants $[29,35]$.

The essential characteristics of bovine [36] and ovine [37] listerial mastitis due to L. monocytogenes is subclinical. Several cases of short-lived excretion of Listeria bacteria in the milk and carriers not showing any symptoms are referred to in the literature, whereas cases of prolonged mastitis caused by Listeria, marked by abnormal milk, increased cell counts and reduced production are not reported $[38,39]$. This incriminates cows to be healthy reservoirs of $L$. monocytogenes [40].

Waste- animal or human - are usually used as fertilizers [41]. Plants and vegetables can become contaminated with Listeria from septic manure-based fertilizers (www.linguee.fr/anglais-francais/traduction/fertilizers + manure.html). Healthy farm animals, reservoirs of pathogenic Listeria, have the potentiality to contaminate meats, dairy products, soil, water, effluents and produce. Also, a recycling condition of listeria strains could be initiated in the farm when the cows shed L. monocytogenes back into the environment after drinking contaminated water [33]. The inter- and intra-farm movement of animals and/or farmers is an important contribution in the listeria dispersion throughout the farm [33]. In addition to the feces, $[40,42,43]$, animal drinking water [42, 44, 45], feeds or feed components [40, 45], sawdust bedding, farmyard manure, soil in which fodder plants were grown, cattle feed such as silage hay cubes, beet pulp and wheat lees [46], pest and wildlife could disseminate $L$. monocytogenes in their feces $[33,47,48]$ are possible sources and routes of $L$. monocytogenes infection for the animals. The success in the control of the previous sources of animal, farm or/and environmental contamination with L. monocytogenes would thereby be in the welfare of the farm animals and farm environment. The faecal excretion of pathogenic Listeria is a predisposing element in the ascending infection of the mammary gland, a feature previously recorded to occur with E. coli or Streptococcus uberis [49]. Despite the inescapable presence of $L$. monocytogenes in the environment, listerial bovine mastitis due to L. monocytogenes is a rare incidence and the organized studies on this topic is limited [38, 39, 50-55].

Another potential explanation for the presence of persistent strains of L. monocytogenes in the farm or/and milk line during the course of our investigation could be due to the residence of mastitic cows and/or a dwelling biofilm in milking machinery and utensils [33]. As shown in the present investigation, the ability of $L$. monocytogenes to produce biofilms is influenced by serotype [56]. Our results revealed a new interesting and additional observation not previously recorded to Listeria species, in the strong affinity of the L. monocytogenes $1 / 2 \mathrm{a}$ (Lineage II) and $4 \mathrm{a}$ and $4 \mathrm{c}$ (Lineage III) to form a biofilm on the abiotic, polystyrene and glass surfaces while Kadam et al. [56] and Doijad et al. [57] found serotypes $1 / 2 \mathrm{~b}$ and $1 / 2 \mathrm{a}$ as strong biofilm formers while serotype $4 \mathrm{~b}$ strains did not exhibit strong biofilm formation $[56,57]$ which could have a drastic outcome in the dairy industry with a consequent hazardous implication on food safety.

Although pathogenicity of $L$. monocytogenes has been related to listeriolysin [58] yet, L. monocytogenes phospholipase (PI-PLC) is also a crucial causal element of pathogenicity $[15,59,60]$ and has been found to be a well grounded indicator for differentiation between the pathogenic and nonpathogenic Listeria species [15]. The pathogenicity of $L$. monocytogenes induced by the PI-PLC is based on the common regulation of the hlyA gene and the $p l c \mathrm{~B}$ gene by the $p r f \mathrm{~A}$ encoded protein [61].

Regulations and practices in the use of antibiotics in the veterinary practice vary widely around the globe and are under the influence of the economic and social circumstances [62]. Clinically, it is of significance to point out that the use of the disc diffusion technique, as implemented in this investigation, is an established universal laboratory assay to determine the susceptibility/ resistance of pathogenic bacteria, to prescribe the right remedy [63]. Several factors contribute to this global discrepancy between researchers in their results [64-76]: i) Variations in the formulation of trials, experiments and adopted procedures, ii) The unnecessary use of antibiotics by veterinarians unable to reach a correct diagnosis, iii) No accurate global map for national and international antimicrobial consumption rates, iv) The rationale use of antibiotics and lack of effective antibiotic stewardship programmes, iii) Variations in antibiotic consumption, both between and within countries, v) Non-prescription antibiotic use, veterinarians might not adequately screen for appropriate use, vi) Differences between countries that have and have not implemented comprehensive national strategies in controlling resistance, vii) Poor performance of molecular tests (screening vs diagnosis, symptomatic vs asymptomatic, active $v s$ latent infection), setting (low $v s$ high prevalence), complexity of test (done by trained $v s$ unskilled staff), and comparator (more or less sensitive than the comparator test), viii) The over the counter purchase of antibiotics used for growth promotion bypassing veterinary superviosion, ix) Unjudicious utilization of antimicrobials in livestock rearing. Interestingly, in Egypt animal farms are quite close to humans, and therefore the hypothesis that ecological resistance close to human settlements 
is anthropogenic in origin must be taken into consideration [62]. It is also of importance to point out that, recording of resistance by the disc diffusion is measured qualitatively thus, any comparison with studies that use other methods of susceptibility testing should not be taken seriously and therefore un-justifiable [77].

The PCR findings are consistent with previously documented research of hlyA gene [30], plcB gene [15], iap gene [32] and actA gene [31] with the respective sets of primers giving no cross-reactions with other bacteria. The PCR employed in our study proved to be specific for distinguishing the four virulence-associated determinants, $p l c \mathrm{~B}, a c t \mathrm{~A}, h l y \mathrm{~A}$ and iap endowed in Listeria spp isolated from the buffalo.

\section{Conclusion}

Pregnant women should not help with calving or milking that have recently given birth or touch the after birth or come into contact with newborn calves as these are potential sources of Listeria. Farmers with deficient immunity are also advised to take the same precautions. Considering this information together with the low but constant level of contamination of bulk milk by L. monocytogenes infected cows, it seems likely that $L$. monocytogenes in cows may be transferred to humans by raw milk or milk that have not been correctly pasteurized. The maintainance of strict hygienic conditions and application of raw milk pasteurization is a must to reduce the risks of human infection with $L$. monocytogenes.

\section{Acknowledgements}

Not applicable.

\section{Funding}

None.

\section{Availability of data and materials}

All data generated or analysed during this study are included in this published article.

\section{Authors' contributions}

$\mathrm{KO}$ involved in the conception of the research idea and methodology design, performed data analysis and interpretation, and prepared the manuscript for publication, AS, UAS, EHM and AO participated in the design of methodology, involved in laboratory work and TZ participated in the manuscript preparation and reviewed the manuscript. All authors read and approved the final manuscript.

\section{Competing interests}

The authors declare that they have no competing interests.

\section{Consent for publication}

Not applicable.

\section{Ethics approval and consent to participate}

This work was performed in accordance with the recommendations in the updated Guide for the Care and Use of Laboratory Animals published by the National Institutes of Health (NRC, 2010). All procedures were approved by the Cairo University Ethical Committee in compliance with the United Kingdom (UK) Animals (scientific procedures) Act of 1986, all required approvals were obtained prior to the experiments.

\section{Author details}

'Department of Microbiology, Faculty of Veterinary Medicine, Cairo University, PO Box 12211, Cairo, Egypt. ${ }^{2}$ Department of Microbiology, Faculty of Veterinary Medicine, Sohag University, Sohag, Egypt. ${ }^{3}$ Department of Bacteriology, Mycology and Immunology, Faculty of Veterinary Medicine, Zagazig University, Zagazig 44519, Egypt. ${ }^{4}$ North Dakota State University, Developmental Science, Fargo, ND 58102, USA.

Received: 12 April 2016 Accepted: 28 October 2016

Published online: 08 November 2016

\section{References}

1. Herodotus 440 B.C. The History of Herodotus By Herodotus Written 440 B.C.E Translated by George Rawlinson Book II Provided by The Internet Classics Archive. Available online at http://classics.mit.edu//Herodotus/history.html

2. Rollinger M. History of milk From "Milch besser nicht" written by Maria Rollinger JOU-Verlag, 2007, 2nd ed. ISBN 978-3-940236-00-5

3. El-Nahrawy MA. Country Pasture/Forage Resource Profile, FAO, 2011 copyright@fao.org or to the Chief, Publishing Policy and Support Branch, Office of Knowledge Exchange, Research and Extension, FAO, Viale delle Terme di Caracalla, 00153 Rome, Italy

4. Camejo A, Carvalho F, Reis O, Leito E, Sousa S, Cabanes D. The arsenal of virulence factors deployed by Listeria monocytogenes to promote its cell infection cycle. Virulence. 2011;2:379-94.

5. Rawool DB, Malik SVS, Shakuntala I, Sahare AM, Barbuddhe SB. Detection of multiple virulence-associated genes in Listeria monocytogenes isolated from bovine mastitis cases. Int J Food Microbiol. 2007;113:201-7.

6. Barza M. Listeriosis and milk. New Engl J Med. 1985;312:438-40.

7. Farber JM, Peterkin PI. Listeria monocytogenes, a food-borne pathogen. Microbiol Rev. 1991;55:476-511.

8. Conly JM, Johnston BL. Listeria: a persistent food-borne pathogen. Can J Infect Dis Med Microbiol. 2008;19:327-8.

9. Morbidity and Mortality Weekly Report. Outbreak of Listeria monocytogenes infections associated with pasteurized milk from a local dairy - Massachusetts, 2007. 2008:57:1097-100

10. Rebagliati V, Philippi R, Rossi M, Troncoso A. Prevention of foodborne listeriosis. Ind J Pathol Microbiol. 2009:52:145-9.

11. Scientific Committee on Emerging and Newly Identified Health Risks, Assessment of the Antibiotic Resistance Effects of Biocides, 19 January 2009 European Commission Health \& Consumer Protection DG Directorate C: Public Health and Risk Assessment Unit C7 - Risk Assessment Office: B232 B-1049 Brussels

12. Forsbäck L, Lindmark-Månsson $H$, Andrén $A$, Svennersten-Sjaunja $K$. Evaluation of quality changes in udder quarter milk from cows with low-tomoderate somatic cell counts. Animal. 2010;4:617-26.

13. Hitchins AS, Jinneman K. Bacteriological Analytical Manual Chapter 10 Detection and Enumeration of Listeria monocytogenes in Foods U.S. Food and Drug Administration 10903 New Hampshire Avenue Silver Spring, MD 20993, Page Last Updated: 02/14/2016

14. Osman KM, Samir A, Orabi A, Zolnikov TR. Confirmed low prevalence of Listeria mastitis in she-camel milk delivers a safe, alternative milk for human consumption. Acta Trop. 2014;130:1-6.

15. Osman KM, Zolnikov TR, Samir A, Orabi A. Prevalence, pathogenic capability, virulence genes, biofilm formation, and antibiotic resistance of Listeria in goat and sheep milk confirms need of hygienic milking conditions. Pathog Global Health. 2014;108:21-9

16. Notermans SHW, Dufrenne J, Leimeister-Wachter M, Domann E, Chakraborty T. Phosphatidylinositol-specific phospholipase C activity as a marker to distinguish between pathogenic and non-pathogenic Listeria species. Appl Environ Microbiol. 1991;57:2666-70.

17. Clark AG, McLauchlin J. Simple color tests based on an alanyl peptidase reaction which differentiate Listeria monocytogenes from other Listeria species. J Clin Microbiol. 1997;35:2155-6.

18. Clinical and Laboratory Standards Institute: Performance Standards for Antimicrobial Susceptibility Testing. CLSI Approved Standard M100-S20. Wayne, PA 2010.

19. Joint FAO/WHO/OIE Expert Meeting on Critically Important Antimicrobials. Report of a meeting held in FAO, Rome, Italy, 26-30 November 2007. FAO, Rome, Italy, and WHO, Geneva, Switzerland 2008

20. World Health Organization: Critically Important Antimicrobials for Human Medicine 2nd Revision 2009. WHO Advisory Group on Integrated 
Surveillance of Antimicrobial Resistance (AGISAR). Department of Food Safety and Zoonoses

21. Menudier A, Bosiraud C, Nicolas JA. Virulence of Listeria monocytogenes serovars and Listeria spp. in experimental infection of mice. J Food Prot. 1991;54:917-21.

22. Wang N, Strugnell R, Wijburg O, Brodnicki T. Measuring bacterial load and immune responses in mice infected with Listeria monocytogenes. J Vis Exp. 2011;e3076, doi: 10.3791/3076

23. Olier M, Pierrea F, Lemaitre JP, Divies C, Rousset A, Guzzo J. Assessment of the pathogenic potential of two Listeria monocytogenes human faecal carriage isolates. Microbiology. 2002;148:1855-62.

24. Fentahun T, Fresebehat A. Listeriosis in small ruminants: a review. Adv Biolog Res. 2012:6:202-9.

25. Seeliger HPR. Listeriosis. New York: Hafner Publishing Co., Inc; 1961.

26. Raja RK, Ramesh N, Maripandi A. Invasion and interaction studies of Salmonella Typhimurium sub sp Enteritidis in vero and MDCK cell lines. Adv Biol Res. 2010;4:86-91.

27. Giacaman RA, Araneda E, Padilla C. Association between biofilm forming isolates of mutans Streptococci and caries experience in adults. Archiv Oral Biol. 2010;55:550-4.

28. Borucki MK, Peppin JD, White D, Loge F, Call DR. Variation in biofilm formation among strains of Listeria monocytogenes. Appl Environ Microbiol. 2003;69:7336-42

29. Vazquez-Boland JA, Kuhn M, Berche P, Chakraborty T, Dominguez-Bernal G, Goebel W, Gonzalez-Zorn B, Wehland J, Kreft J. Listeria pathogenesis and molecular virulence determinants. Clin Microbiol Rev. 2001;14:584-640.

30. Paziak-Domanska B, Bogulawska E, Wiekowska-Szakiel M, Kotlowski R, Rozalska B, Chmiela M, Kur J, Dabrowski W, Rudnicka W. Evaluation of the API test, phosphatidylinositol-specific phospholipase $C$ activity and PCR method in identification of Listeria monocytogenes in meat foods. FEMS Microbiol Lett. 1991;171:209-14.

31. Suarez $\mathrm{M}$, Vazquez-Boland JA. The bacterial actin nucleter protein ActA is involved in epithelial cell invasion by Listeria monocytogenes. www.ncbi.nlm. nih.gov/pubmed [Accession No. AF103807] 2001

32. Furrer $\mathrm{B}$, Candrian $\mathrm{U}$, Hoefelein $\mathrm{CH}$, Luethy J. Detection and identification of Listeria monocytogenes in cooked sausage products and in milk by in vitro amplification of haemolysin gene fragments. J Appl Bacteriol. 1991;70:372-9.

33. Latorre AA, Van Kessel JAS, Karns JS, Zurakowski MJ, Pradhan AK, Boor KJ, Adolph E, Sukhnanand S, Schukken YH. Increased in vitro adherence and on-farm persistence of predominant and persistent Listeria monocytogenes strains in the milking system. Appl Environ Microbiol. 2011;77:3676-84.

34. Choi YC, Park BK, Oh DH. Polymerase chain reaction for the rapid detection of Listeria monocytogenes in foods using HlyA gene primers. J Korean Soc Food Sci Nutr. 2000;29:1016-24.

35. Ramaswamy V, Cresence VM, Rejitha JS, Lekshmi MU, Dharsana KS, Prasad SP, Vijila HM. Listeria: review of epidemiology and pathogenesis. J Microbiol Immunol Infect. 2007:40:4-13.

36. Bourry A, Poutrel B. Bovine mastitis caused by Listeria monocytogenes: kinetics of antibody response in serum and milk after experimental infection. J Dairy Sci. 1996;79:2189-95.

37. Fthenakis GC, Saratsis PH, Tzora A, Linde K. Naturally occurring subclinical ovine mastitis associated with Listeria monocytogenes. Small Rum Res. 1998;31:23-7.

38. van Dalen AMMJ, Jaartsveld FHJ. Listeria - mastitis bij het rund. Tijdschr Diergeneeskd. 1988;113:380-3.

39. Winter P, Schilcher F, Bagò Z, Schoder D, Egerbacher M, Baumgartner W, Wagner M. Clinical and histopathological aspects of naturally occurring mastitis caused by Listeria monocytogenes in cattle and ewes. J Vet Med B Infect Dis Vet Public Health. 2004;51:176-9.

40. Nightingale KK, Schukken YH, Nightingale CR, Fortes ED, Ho AJ, Her Z, Grohn YT, McDonough PL, Wiedmann M. Ecology and transmission of Listeria monocytogenes infecting ruminants and in the farm environment. Appl Environ Microbiol. 2004;70:4458-67.

41. De Luca G, Zanetti F, Fateh-Moghadm P, Stampi S. Occurrence of Listeria monocytogenes in sewage sludge. Zentralblatt Hygiene Umweltmedizin. 1998;201:269-77.

42. Nightingale KK, Fortes ED, Ho AJ, Schukken YH, Grohn YT, Wiedmann M. Evaluation of farm management practices as risk factors for clinical listeriosis and fecal shedding of Listeria monocytogenes in ruminants. J Am Vet Med Assoc. 2005;227:1808-14.

43. Lyautey E, Hartmann A, Pagotto F, Tyler K, Lapen DR, Wilkes G, Piveteau P, Rieu A, Robertson WJ, Medeiros DT, Edge TA, Gannon V, Topp E.
Characteristics and frequency of detection of fecal Listeria monocytogenes shed by livestock, wildlife, and humans. Can J Microbiol. 2007;53:1158-67.

44. Latorre AA, Van Kessel JA, Karns JS, Zurakowski MJ, Pradhan AK, Zadoks RN, Boor KJ, Schukken YH. Molecular ecology of Listeria monocytogenes: evidence for a reservoir in milking equipment on a dairy farm. Appl Environ Microbiol. 2009;75:1315-23.

45. Mohammed HO, Stipetic K, McDonough PL, Gonzalez RN, Nydam DV, Atwill ER. Identification of potential on-farm sources of Listeria monocytogenes in herds of dairy cattle. Am J Vet Res. 2009;70:383-8.

46. Yoshida T, Kato $Y$, Sato M, Hirai K. Sources and routes of contamination of raw milk with Listeria monocytogenes and its control. J Vet Med Sci. 1998;60:1165-8.

47. Ho AJ, Ivanek R, Gröhn YT, Nightingale KK, Wiedmann M. Listeria monocytogenes fecal shedding in dairy cattle shows high levels of day-today variation and includes outbreaks and sporadic cases of shedding of specific L. monocytogenes subtypes. Prev Vet Med. 2007;80:287-305.

48. Kasalica A, Vuković $\mathrm{V}$, Vranješ $\mathrm{A}$, Memiši N. Listeria monocytogenes in milk and dairy products. Biotechnol Anim Husb. 2011;27:1067-82.

49. Bramley AJ. Mastitis and machine milking. In: Bramley AJ, Dodd FH, Mein GA, Bramley JA, editors. Machine milking and lactation. Berkshire: Insight Books; 1992. p. 342-72.

50. Errebo-Larsan $\mathrm{H}$, Jensen J. In: Ivanov I, editor. Proceedings of the 7th International Symposium on Problems of Listeriosis. Varna, Bulgaria. 1979. p. 193

51. Gitter M, Bradley R, Blampied PH. Listeria monocytogenes infection in bovine mastitis. Vet Rec. 1980;107:390-3.

52. Sharp MW. Bovine mastitis and Listeria monocytogenes. Vet Rec. 1987;121:512-3.

53. Fedio WM, Schoonderwoerd M, Shute RH, Jackson H. A case of bovine mastitis caused by Listeria monocytogenes. Can Vet J. 1990;31:773-5.

54. Jensen NE, Aarestrup FM, Jensen J, Wegener HC. Listeria monocytogenes in bovine mastitis. Possible implication for human health. Int J Food Microbiol. 1996;32:209-16.

55. Shome BR, Shakuntala I, Shome R, Kumar A. Isolation of Listeria monocytogenes from mastitis case in Holstein-Friesian cattle. Indian Association of Veterinary Microbiologists, Immunologists and Specialists in Infectious Diseases. Annual Conference, Umiam, Barapani, 7 Feb. Abs. No. PP:05, 2003;p. 52.

56. Kadam SR, den Besten HM, van der Veen S, Zwietering MH, Moezelaar $\mathrm{R}$, Abee T. Diversity assessment of Listeria monocytogenes biofilm formation: impact of growth condition, serotype and strain origin. Int J Food Microbiol. 2013;165:259-64.

57. Doijad SP, Barbuddhe SB, Garg S, Poharkar KV, Kalorey DR, Kurkure NV, Rawool DB, Chakraborty T. Biofilm-forming abilities of Listeria monocytogenes serotypes isolated from different sources. PLoS One. 2015; 10:e0137046.

58. Tabouret M, DeRycke J, Audurier A, Poutrel B. Pathogenicity of Listeria monocytogenes isolates in immunocompromised mice in relation to production of listeriolysin. J Med Microbiol. 1991;34:13-8.

59. Marquis $\mathrm{H}$, Doshi V, Portnoy DA. The broad-range phospholipase $\mathrm{C}$ and a metalloprotease mediate listeriolysin O-independent escape of Listeria monocytogenes from a primary vacuole in human epithelial cells. Infect Immun. 1995;63:4531-4.

60. Smith GA, Marquis $H$, Jones $S$, Johnston NC, Portnoy DA, Goldfine $H$. The two distinct phospholipases $C$ of Listeria monocytogenes have overlapping roles in escape from a vacuole and cell-to-cell spread. Infect Immun. 1995; 63:4231-7.

61. Goldfine H, Knob C. Purification and characterization of Listeria monocytogenes phosphatidylinositol-specific phospholipase C. Infect Immun. 1992;60:4059-67.

62. Laxminarayan R, Duse A, Wattal C, Zaidi AKM, Wertheim HFL, Sumpradit N, Vlieghe E, Hara GL, Gould IM, Goossens H, Greko C, So AD, Bigdeli M, Tomson G, Woodhouse W, Ombaka E, Peralta AQ, Qamar FN, Mir F, Kariuki S, Bhutta ZA, Coates A, Bergstrom R, Wright GD, Brown ED, Cars O. Antibiotic resistance - the need for global solutions. Lancet Infect. Dis Comm. Published online November 17, 2013 http://dx.doi.org/10.1016/ S1473-3099(13)70318-9 pp. 1-42

63. Kalmus P, Aasmäe B, Kärssin A, Orro T, Kask K. Udder pathogens and their resistance to antimicrobial agents in dairy cows in Estonia. Acta Vet Scand. 2011;53:4.

64. Hof H, Nichterlein T, Kretschmar M. Management of listeriosis. Clin Microbiol Rev. 1997;10:345-57. 
65. Threlfall J, Skinner A, McLauchlin J. Antimicrobial resistance in Listeria monocytogenes from humans and food in the UK. Clin Microbiol Infect. 1998:4:410-2.

66. Arslan S, Özdemir F. Prevalence and antimicrobial resistance of Listeria spp. in homemade white cheese. Food Control. 2008;19:360-3.

67. Davis JA, Jackson CR. Comparative antimicrobial susceptibility of Listeria monocytogenes, L. innocua, and L. welshimeri. Microb Drug Resis. 2009;15:27-32.

68. Filiousis G, Johansson A, Frey J, Perreten V. Prevalence, genetic diversity and antimicrobial susceptibility of Listeria monocytogenes isolated from open-air food markets in Greece. Food Control. 2009;20:314-7.

69. Nwanchukwu NC, Orji FA, Amaike Jl. Isolation and characterization of Listeria monocytogenes from kunu, a locally produced beverage marketed in different markets in Abia State of Nigeria. Australian J Basic Appl Sci. 2009;3:4432-6.

70. Pesavento G, Ducci B, Nieri D, Comodo N, Lo Nostro A. Prevalence and antibiotic susceptibility of Listeria spp. isolated from raw meat and retail foods. Food Control. 2010;21:708-13.

71. Stonsaovapak S, Boonyaratanakornkit M. Prevalence and antimicrobial resistance of Listeria species in food products in Bangkok, Thailand. J Food Safety. 2010;30:154-61.

72. Issa ZM, Mustakim M, Mohamed SAS, Muda NM, Yen LH, Radu S. Antibiogram Profiles of Listeria monocytogenes isolated from foods. 2011 2nd International Conference on Biotechnology and Food Science IPCBEE vol.7 (c) (2011) IACSIT Press, Singapore

73. Ruiz-Bolivar Z, Neuque-Rico MC, Poutou-Piñales RA, Carrascal-Camacho AK, Mattar S. Antimicrobial susceptibility of Listeria monocytogenes food isolates from different cities in Colombia. Foodborne Pathog Dis. 2011;8:913-9.

74. Rahimi E, Momtaz H, Sharifzadeh A, Behzadnia A, Ashtari MS, Esfahani SZ, Riahi M, Momeni M. Prevalence and antimicrobial resistance of Listeria species isolated from traditional dairy products in Chahar Mahal \& Bakhtiyari, Iran. Bulg J Vet Med. 2012;15:115-22.

75. Yakubu Y, Salihu MD, Faleke OO, Abubakar MB, Junaidu AU, Magaji A, Gulumbe ML, Aliyu RM. Prevalence and antibiotic susceptibility of Listeria monocytogenes in raw milk from cattle herds within Sokoto Metropolis, Nigeria. Sokoto J Vet Sci. 2012;10:13-7.

76. Soni DK, Singh RK, Singh DV, Dubey SK. Characterization of Listeria monocytogenes isolated from Ganges water, human clinical and milk samples at Varanasi, India. Infect Gen Evol. 2013;14:83-91.

77. Schwarz S, Silley P, Shabbir S, Woodword N, van Duijkeren E, Johnson AP, Gaastra W. Editorial. Assessing the antimicrobial susceptibilty of bacteria obtained from animals. Vet Microbiol. 2009;141:1-4.

\section{Submit your next manuscript to BioMed Central and we will help you at every step:}

- We accept pre-submission inquiries

- Our selector tool helps you to find the most relevant journal

- We provide round the clock customer support

- Convenient online submission

- Thorough peer review

- Inclusion in PubMed and all major indexing services

- Maximum visibility for your research

Submit your manuscript at www.biomedcentral.com/submit 